\title{
MICRONUTRIENT CONCENTRATION AND CONTENT IN PASSION FRUIT LEAVES UNDER SAMPLING METHODS AND N-K FERTILIZATION RATES ${ }^{1}$
}

\author{
PAULO AUGUSTO PEREIRA LOPES ${ }^{2}$, RODINEI FACCO PEGORARO ${ }^{3}$, \\ DEIVISSON FERREIRA DA SILVA ${ }^{4}$, VICTOR MARTINS MAIA ${ }^{5}$, ANANIAS COSTA MEDEIROS 6
}

ABSTRACT - Balanced uptake of micronutrients by the passion fruit plant is essential for increased production and fruit quality. However, similar fertilizer management in varieties with different productive capacities and high levels of nitrogen and potassium can cause nutritional disorders in plants. The objective of this study was to evaluate leaf micronutrient concentrations and contents in passion fruit as affected by two different sampling methods, different $\mathrm{N}-\mathrm{K}$ fertilization proportions, and different cultivars. The study was conducted in a randomized block design, with three replications, following a $4 \times 6$ factorial arrangement consisting of four cultivars of yellow passion fruit (BRS Gigante Amarelo, IAC 275, BRS Ouro Vermelho, and BRS Sol do Cerrado) and six application rates ofN-K $\mathrm{O}$ fertilizer $(0-0,50-125,100-250,150-375$, 200-500, and 250-625 kg ha-1 year-1). Two leaf sampling methods (leaf located at a position adjacent to the fruit, and leaf located at the end of the fruit-bearing branch) were adopted for nutritional assessment. At 240 days after planting passion fruit seedlings in the experimental area, 20 leaves per plot were sampled. Higher accumulated micronutrient contents were obtained in the adjacent leaves, possibly because of greater leaf weight (more fully developed leaf) compared to the standard leaf. The cultivar IAC 275 had lower concentration and content of $\mathrm{Cu}, \mathrm{Fe}, \mathrm{e} \mathrm{Mn}$ in the adjacent leaf, indicating variations in the levels of micronutrients among the cultivars and different micronutrient demands by the cultivars studied. $\mathrm{N}$ and $\mathrm{K}$ fertilization had less effect on leaf micronutrient concentration and content, but the $\mathrm{Zn}$ concentration and content decreased in the standard leaf of the BRS Gigante Amarelo cultivar, and $\mathrm{Cu}$ decreased in the standard leaf of the BRS Ouro Vermelho cultivar.

Index terms: Passiflora edulis Sims; Cultivars, Leaf content.

\section{TEOR E ACÚMULO DE MICRONUTRIENTES EM FOLHAS DE MARACUJAZEIRO SOB MÉTODOS DE AMOSTRAGEM E ADUBAÇÕES N-K}

\begin{abstract}
RESUMO - A absorção equilibrada dos micronutrientes pelo maracujazeiro é essencial para o aumento da produção e qualidade de seus frutos. No entanto, a utilização de cultivares com distintas capacidades produtivas e doses elevadas de nitrogênio e potássio podem levar a desordens nutricionais nas plantas. Objetivou-se avaliar os teores e acúmulos foliares de micronutrientes em maracujazeiros, sob dois métodos de amostragem foliar e adubação com $\mathrm{N}$ e K. O delineamento utilizado foi o em blocos casualizados, com três repetições, no esquema fatorial $4 \times 6$, consistindo em quatro cultivares de maracujazeiro- azedo (BRS Gigante Amarelo, IAC 275, BRS Ouro Vermelho e BRS Sol do Cerrado) e seis doses de N-K $20(0-0 ; 50-125 ; 100-250 ; 150-$ $375 ; 200-500$ e $250-625 \mathrm{~kg} \mathrm{ha}^{-1} \mathrm{ano}^{-1}$ ). Foram adotados dois métodos de amostragem foliar (folha localizada na posição adjacente ao fruto e folha localizada no final do ramo frutífero) para a avaliação nutricional. Aos 240 dias após plantio das mudas de maracujazeiro na área experimental, foram amostradas 20 folhas por parcela. Os maiores acúmulos de micronutrientes foram obtidos nas folhas adjacentes, possivelmente em virtude da maior massa de folhas (folhas totalmente desenvolvidas) em comparação àqueles obtidos nas folhas-padrão. A cultivar IAC 275 teve menor teor e acúmulo médio de $\mathrm{Cu}, \mathrm{Fe}$ e $\mathrm{Mn}$ na folha adjacente, indicando variações nos teores de micronutrientes entre as cultivares e a existência de distintas demandas de micronutrientes pelas cultivares estudadas. As adubações com N e K tiveram menor interferência nos teores e acúmulos de micronutrientes foliares, mas reduziram o teor e o acúmulo foliar de $\mathrm{Zn}$ na folha-padrão da cultivar Gigante Amarelo, de $\mathrm{Cu}$ na folha adjacente da cultivar Ouro Vermelho.
\end{abstract}

Termos para indexação: Passiflora edulis Sims, Cultivares, Teor foliar.

'(Paper 034-16). Received February 22, 2016. Accepted October 11, 2016.

${ }^{2}$ Agronomist, Master's degree student in Plant Production in the Semiarid Region at Unimontes, Janaúba-MG, Brazil. E-mail: paulo_ap117@hotmail.com

${ }^{3}$ Professor of the Instituto de Ciências Agrárias, Universidade Federal de Minas Gerais. Avenida Universitária, 1.000 - Bairro Universitário - Montes Claros - MG - CEP: 39.404-547. Brazil. *Corresponding author. E-mail: rodinei_pegoraro@yahoo.com.br

${ }^{4}$ Agronomist, Professor of the Instituto Federal Catarinense, Rodovia BR 280, km 27, Porto Grande, Araquari, Santa Catarina, CEP 89245-000. E-mail: deivisson.silva@ifc.edu.br

${ }^{5}$ Agronomist, Dr., Professor of the Agrarian Sciences Department, Unimontes, Janaúba, MG, Brazil. E-mail: victor.maia@unimontes.br ${ }^{6}$ Agronomist of the Consórcio União da Serra Geral company, Janaúba, MG, Brazil. E-mail: ananias.medeiros@hotmail.com 


\section{INTRODUCTION}

Passion fruit is one of the fruit crops of Brazil that provide higher economic return to rural producers and companies. In the municipality of Janaúba, in the north of Minas Gerais, average yield in 2013 was $20 \mathrm{t} \mathrm{ha}^{-1}$ (IBGE, 2013), higher than the average yield obtained for the state of Minas Gerais. However, this yield is still considered low from the perspective of the yield potential of the crop, which is higher than $50 \mathrm{t} \mathrm{ha}^{-1}$.

To obtain yield increases in passion fruit, the nutritional requirements of the plants must be supplied by fertilization, when necessary. In this respect, adequate determination of the nutritional state of the passion fruit plants is indispensable (SILVA JÚNIOR et al., 2013). Nevertheless, it must be highlighted that the leaf nutrient concentrations in passion fruit plants are affected by the season in which sampling occurs, fertilization, the cultivars planted, and other factors (BORGES et al., 2002; NATALE et al., 2006; SOUZA et al., 2013); this results in divergence in diagnosis of the nutritional state and in recommendation of fertilization.

Fertilization with nitrogen $(\mathrm{N})$ and potassium $(\mathrm{K})$ is important for maintaining the metabolic functions of the plant, such as composing amino acids and chlorophylls and synthesizing carbohydrates and enzyme activators (BORGES et al., 2002; PETTIGREW, 2008). Nitrogen and potassium fertilization causes synergistic and inhibitory effects on plant micronutrient uptake (NATALE et al., 2006; MUNER et al., 2011).

The use of $\mathrm{KCl}$ as a source of $\mathrm{K}$ in growing sour passion fruit increased the leaf concentrations of $\mathrm{Cu}, \mathrm{B}$, and Mn (MENEZES et al., 2012). In general, balanced fertilization with $\mathrm{N}$ and $\mathrm{K}$ increases the uptake of most micronutrients (NATALE et al., 2006; WANG et al., 2013); however, high application rates of $\mathrm{K}$ can inhibit uptake of cationic micronutrients (ALMEIDA et al., 2015).

Micronutrient concentrations can vary as a result of the age or the position of the leaf sampled; however, this variation depends on the nutrient and the species under study (FREITAS et al., 2007; RODRIGUES et al., 2010). Santos et al. (2002) described an increase in $\mathrm{Fe}$ and $\mathrm{Mn}$ concentrations and decrease in $\mathrm{Cu}$ and $\mathrm{Zn}$ concentrations from new leaves to older leaves in dwarf coconut. Marschner (1995) states that micronutrients with little mobility, such as B and Mn, have higher concentrations in older leaves of the plants and leaves farther from the apical region of the branches. However, there are variations in sampling procedures in relation to age, leaf position on the branch, and the phenological phase of the passion fruit plant that lead to indefinition in sampling standards for leaf diagnosis.

Leaf diagnosis is an indispensable tool in diagnosis of possible micronutrient nutritional disorders and in evaluation of the nutritional state of the plants (ABREU et al., 2007). High yielding plant species have been extensively grown with excessive NPK fertilization in many countries, which brings about micronutrient deficiencies (CAKMARK, 2002).

In recent decades, micronutrients have drawn greater interest among Brazilian technicians and farmers for the most diverse soil, climate, and crop conditions in Brazil. However, there are few studies on application rates of $\mathrm{N}$ and $\mathrm{K}$ in sour passion fruit cultivars with high yield potential concerning procedures that define leaf nutrient concentrations and contents and methods of evaluation for efficient nutritional diagnosis with lower rates of variation during the crop cycle. Thus, the aim of this study was to evaluate leaf micronutrient concentrations and content in passion fruit plants under two methods of leaf sampling and different $\mathrm{N}$ and $\mathrm{K}$ fertilization rates.

\section{MATERIALS AND METHODS}

The study was conducted in the municipality of Janaúba, MG, Brazil, in the period from April 2013 to April 2014. The location of the study is $15^{\circ} 43^{\prime} 48^{\prime \prime}$ $\mathrm{S}$ and $43^{\circ} 19^{\prime} 24^{\prime \prime} \mathrm{W}$, at $516 \mathrm{~m}$ altitude. Climate in the region is Aw according to the Köppen classification, that is, tropical climate with dry winter; and the soil of the experimental area is classified as a Latossolo Vermelho (EMBRAPA, 2013).

A randomized block experimental design was used with three replications, and the experimental units were in a $4 \times 6$ factorial arrangement. This factorial arrangement corresponds to four sour passion fruit cultivars (BRS Gigante Amarelo, IAC 275, BRS Ouro Vermelho, and BRS Sol do Cerrado) and six application rates of $\mathrm{N}-\mathrm{K}_{2} \mathrm{O}(0-0,50-125,100-$ $250,150-375,200-500$, and 250-625 kg ha ${ }^{-1}$ year $\left.^{-1}\right)$. The mean recommended application rate (150-375 $\mathrm{kg} \mathrm{ha}^{-1}$ year $^{-1}$ ) was estimated to obtain yields greater than $35 \mathrm{t} \mathrm{ha}^{-1}$ of fruit, according to Sousa and Borges (2011) for irrigated systems, though adaptations were made concerning parceling of fertilization and the application of fertilizers.

The sources of $\mathrm{N}$ and $\mathrm{K}$ used were urea, potassium chloride, and potassium sulfate, applied in topdressing and parceled out in four applications from two to eight months after planting; the first was 
made at two months after planting and the others every two months afterwards. These fertilizers were diluted in $60 \mathrm{~L}$ of water, and $1 \mathrm{~L}$ of dilution was applied to each plant in a strip of approximately 0.2 $\mathrm{m}$ width around the trunk at a distance of $0.1 \mathrm{~m}$ from it up to 150 days after planting (DAP), increasing to $0.3 \mathrm{~m}$ from the trunk as of $180 \mathrm{DAP}$, according to Borges et al. (2003).

The experimental plots consisted of five plants at a spacing of $2.5 \times 2 \mathrm{~m}$ in a single row, and the three center plants were used for evaluation, for a total of $15 \mathrm{~m}^{2}$ of useful plot area. Before planting the passion fruit, the area had grown pineapple (July 2009 to October 2011), which had been fertilized with approximately $20 \mathrm{t} \mathrm{ha}^{-1}$ of cattle manure, 600 $\mathrm{kg} \mathrm{ha}^{-1}$ of N, $240 \mathrm{~kg} \mathrm{ha}^{-1}$ of $\mathrm{P}_{2} \mathrm{O}_{5}$, and $800 \mathrm{~kg} \mathrm{ha}^{-1}$ of $\mathrm{K}_{2} \mathrm{O}$. At the end of pineapple growing, the plant residues ( $30 \mathrm{t} \mathrm{ha}^{-1}$ dry matter) were left on the soil surface, and the area remained fallow for 18 months.

After that, the area was sprayed with glyphosate to eliminate weeds and form a new mulch. At that time, soil samples were collected from the area (at depths of 0-20 and 20-40 cm) for chemical and physical characterization of the soil (Table 1), according to the methods described by Embrapa (1997).

Soil tillage was performed in the experimental area in a conventional manner through plowing and two passes with a disk in preplanting. Seedlings of the passion fruit cultivars were produced in a nursery from seeds. Two seeds per plastic bag, containing 0.5 L of substrate, were used. Soon after germination, the seedlings were thinned, leaving only the seedling with greater vigor in each container. For preparation of $1 \mathrm{~m}^{3}$ of substrate, the following measures were adopted: the ratio of $3: 1: 1$ of soil, cattle manure, and sand, $5 \mathrm{~kg}$ of simple superphosphate, $1 \mathrm{~kg}$ of potassium chloride, $1 \mathrm{~kg}$ of dolomitic lime, and 50 $\mathrm{g}$ of FTE-BR12.

Two months after sowing, the seedlings had three pairs of defined leaves and were ready for planting. This was performed in April 2013 in plant holes of $0.4 \times 0.4 \times 0.4 \mathrm{~m}$. These holes were fertilized with $10 \mathrm{~L}$ of cattle manure, $100 \mathrm{~g}$ of dolomitic lime, $50 \mathrm{~g}$ of FTE-BR12, and $550 \mathrm{~g}$ of simple superphosphate. The cattle manure contained the following total nutrient concentrations: $0.90 \mathrm{dag}$ $\mathrm{kg}^{-1} \mathrm{~N}, 0.12$ dag kg-1 $\mathrm{P}, 0.50$ dag kg-1 $\mathrm{K}, 0.26$ dag $\mathrm{kg}^{-1}$

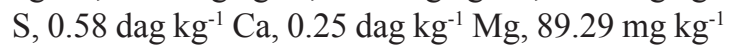
$\mathrm{Zn}, 18.85 \mathrm{mg} \mathrm{kg}^{-1} \mathrm{Cu}, 8623.30 \mathrm{mg} \mathrm{kg}^{1} \mathrm{Fe}, 306.65$ $\mathrm{mg} \mathrm{kg}{ }^{-1} \mathrm{Mn}$, and $9.85 \mathrm{mg} \mathrm{kg}^{-1} \mathrm{~B}$.

The crop was grown in a vertical trellis system with a wire at a height of $1.70 \mathrm{~m}$. The rows consisted of two fencings at an angle of $30^{\circ}$ at the top and eight posts spaced at $5 \mathrm{~m}$ in the center of the row, with a total of 20 plant rows. The plants, after going beyond $10 \mathrm{~cm}$ above the wire, were pruned in order to break apical dominance, thus allowing emission of two new lateral branches, which were trained in opposite directions.

The lateral branches were trained until reaching $1 \mathrm{~m}$ on both sides and were then pruned to break apical dominance and favor the growth of productive branches. The productive branches were trained to a distance of $40 \mathrm{~cm}$ from the soil as a manner of preventing diseases caused by plant pathogens Throughout the crop period, thinning was performed by pruning the stem and lateral branches, and growth, always maintaining a height of $40 \mathrm{~cm}$ above the ground.

The plants were irrigated by microspray nozzles with a flow of $120 \mathrm{~L} \mathrm{~h}^{-1}$, which were arranged in 10 rows at an approximate distance of $1 \mathrm{~m}$ from the root collar of the plants, with a total of 10 spray nozzles per row. Irrigation was applied according to crop needs, following the crop coefficient $(\mathrm{Kc})$ indicated by Silva and Klar (2002).

Weeds were controlled by application of glyphosate between the rows at the rate of $2 \mathrm{~L} \mathrm{ha}^{-1}$ in four applications throughout the crop season. Caterpillars and insects were controlled with pyrethroid and imidacloprid, respectively, at the

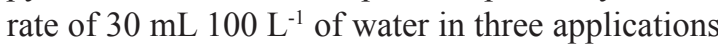
of pyrethroid and two of imidacloprid during the crop season.

Two methods of leaf sampling were adopted for nutritional characterization of the plants: taking leaves from the position adjacent to the fruit (adjacent leaf) and leaves from the end of the fruit-bearing branch (standard leaf). Leaves were sampled after flowering of the passion fruit plants, at approximately eight months after planting, collecting 20 leaves per experimental plot. The standard leaf was sampled according to Malavolta et al. (1997) through collecting the 4th leaf of the vegetative branch, counting from the apex to the base of the branch. The method of sampling leaves from the adjacent position was adapted from Marchal and Bourdeaut (1972), collecting the leaves adjacent to the fruit in the initial phase of development (fruit of approximately $2 \mathrm{~cm}$ length), instead of sampling leaves at the axils of the flower buds.

The leaf samples were dried at $65^{\circ} \mathrm{C}$ in a forced air circulation oven for $72 \mathrm{~h}$ and ground in a Wiley mill for later determination of dry matter weight and micronutrient concentrations, according to Silva (2009). Based on nutrient concentration and on dry matter weight, the mean content of 
micronutrients in 10 leaves of the passion fruit plants was calculated through the following equation:

$$
M C=\frac{\text { Concentration } x \text { DMW }}{f} \times 10
$$

In which: leaves $^{-1}$ );

$\mathrm{MC}=$ micronutrient content in 10 leaves $(\mathrm{mg}$

Concentration $=$ micronutrient concentration in the leaf $\left(\mathrm{mg} \mathrm{kg}^{-1}\right)$;

$\mathrm{DMW}=$ leaf dry matter weight $\left(\mathrm{g} \mathrm{leaf}^{-1}\right)$;

$=1000$, corresponds to the unit conversion factor (kilograms to grams).

The variables under study were subjected to analysis of variance $(p<0.05)$. The qualitative factor (cultivars) was compared by the Tukey test $(\mathrm{p}<0.05)$ and the quantitative factor ( $\mathrm{N}$ and $\mathrm{K}$ application rates) was adjusted through regression analyses on the Sisvar statistical program (FERREIRA, 2011). The models were fitted based on the significance of the parameters and on the coefficient of determination.

\section{RESULTS AND DISCUSSION}

The micronutrient concentrations and contents were significantly $(\mathrm{p}<0.05)$ affected by the dual interaction between the passion fruit cultivars versus $\mathrm{N}$ and $\mathrm{K}$ application rates in the two leaf sampling methods (Table 2).

The mean concentrations of $\mathrm{Zn}, \mathrm{Cu}, \mathrm{Fe}, \mathrm{Mn}$, and $\mathrm{B}$ in the standard leaf of the cultivars studied corresponded to $21,6,100,68$, and $56 \mathrm{mg} \mathrm{kg}^{-1}$, respectively, and in the adjacent leaf corresponded to $19,6,140,65$, and $62 \mathrm{mg} \mathrm{kg}^{-1}$, respectively. Among these mean concentrations, only the concentration of $\mathrm{Fe}$ in the adjacent leaves was considered adequate in comparison to the sufficiency range (120-200 mg $\mathrm{kg}^{-1}$ for $\mathrm{Fe}$ ) indicated by Malavolta et al. (1997). However, the mean leaf concentrations of $\mathrm{Zn}, \mathrm{Cu}$, and $\mathrm{Mn}$ in the passion fruit leaves were below the sufficiency range of $25-40 \mathrm{mg} \mathrm{kg}^{-1}$ for $\mathrm{Zn}$, of 10-20 $\mathrm{mg} \mathrm{kg}^{-1}$ for $\mathrm{Cu}$, and of $400-600 \mathrm{mg} \mathrm{kg}^{-1}$ for $\mathrm{Mn}$, indicated by the same author. Concerning $\mathrm{B}$, the leaf concentrations are above the sufficiency range indicated by Malavolta et al. (1997), which is 40-50 $\mathrm{mg} \mathrm{kg}^{-1}$ of B.

In the adjacent leaf of the cultivars Ouro Vermelho and Sol do Cerrado, an increase was found in the content of dry matter weight with the increase in the N-K application rate up to 150-375 and 128$319 \mathrm{~kg} \mathrm{ha}^{-1}$, respectively (Figure 1). However, for the cultivar IAC 275 , this characteristic decreased in a linear manner. In the cultivars Ouro Vermelho and Sol do Cerrado, the increase in leaf dry matter was related to a probable increase in leaf carbohydrate and protein synthesis, brought about by greater availability of $\mathrm{N}$ and $\mathrm{K}$ to plants after fertilization at intermediate application rates since these nutrients have specific functions in synthesis of carbohydrates and proteins (BORGES et al., 2002; OLIVEIRA et al., 2015).

In the adjacent leaf of the cultivar IAC 275, lower contents of $\mathrm{Cu}, \mathrm{Fe}$, and $\mathrm{Mn}$ were obtained in comparison to the other cultivars (Figures 2, 3, and 4). This result was related to reduction in leaf dry matter weight with the increase in $\mathrm{N}$ and $\mathrm{K}$ application rates (Figure 1). Lizarazo et al. (2013) obtained reduction in specific leaf area (division between leaf area and leaf weight) in Passiflora tripartita var. mollissima after the application of $\mathrm{N}$ and $\mathrm{K}$ rates in comparison to the unfertilized treatment, and they described that the increase in potassium availability leads to production of smaller and thicker leaves.

The increase in $\mathrm{N}$ and $\mathrm{K}$ application rates reduced the concentration and content of $\mathrm{Zn}$ in the standard leaf for the Gigante Amarelo cultivar (Figure 2). However, in the cultivars IAC 275 and Ouro Vermelho, no effect from the application rates was found, and in the Sol do Cerrado cultivar, there was an increase in leaf $\mathrm{Zn}$ concentration and content with the increase in N-K fertilization, indicating the heterogeneity of the effects of nitrogen and potassium fertilization on $\mathrm{Zn}$ uptake by the cultivars studied.

In the leaves sampled in the adjacent position, no difference was found among the cultivars studied for $\mathrm{Zn}$ concentration and content with an increase in the $\mathrm{N}$ and $\mathrm{K}$ application rates, and the mean value was $18.64 \mathrm{mg} \mathrm{kg}^{-1}$ for concentration and $0.69 \mathrm{mg}$ leaves $^{-1}$ for content (Figure 2).

Reduction in the $\mathrm{Zn}$ concentrations in the standard leaf of the Gigante Amarelo cultivar may be linked to the synergistic effect of the application of $\mathrm{N}$ favoring uptake of $\mathrm{P}$, which contributes to the formation of insoluble phosphates in the plant, reducing the translocation of $\mathrm{Zn}$ to the leaves. According to Muner et al. (2011), increases in the P concentrations in the plant reduces the physiological availability of $\mathrm{Zn}$, that is, it diminishes its solubility and mobility, caused by $\mathrm{Zn}$ precipitation in the form of $\mathrm{Zn}$ phosphate.

In contrast, the increase in leaf $\mathrm{Zn}$ concentration and content in the Sol do Cerrado cultivar (Figure 2) may be explained by the greater efficiency of the plant in taking up the $\mathrm{Zn}$ made available by the ammonium nitrification process and reduction in soil $\mathrm{pH}$ after the application of higher 
nitrogen rates. According to Caires and Milla (2016), the use of ammoniacal nitrogen fertilizer or urea fertilizer, containing nitrogen in the form of $\mathrm{N}-\mathrm{NH}_{2}$ or $\mathrm{N}-\mathrm{NH}_{4}$, reduces soil $\mathrm{pH}$, because in the nitrification process, each molecule of $\mathrm{NH}_{4}^{+}$that is oxidized to $\mathrm{NO}_{3}^{-}$releases two protons $\left(\mathrm{H}^{+}\right)$. In this condition of lower soil $\mathrm{pH}$, there is an increase in the availability of micronutrients to plants (NEVES et al., 2008).

The $\mathrm{Cu}$ concentrations and contents in the adjacent and standard leaves in the cultivars Gigante Amarelo, IAC 275, and Sol do Cerrado were not affected by the $\mathrm{N}$ and $\mathrm{K}$ application rates (Figure 2). In the adjacent leaf of the Ouro Vermelho cultivar, the $\mathrm{Cu}$ concentration and content decreased with the increase in fertilization up to the recommended $188 \mathrm{~kg} \mathrm{ha}^{-1}$ of $\mathrm{N}$ and $469 \mathrm{~kg} \mathrm{ha}^{-1}$ of $\mathrm{K}$ (Figure 2). These divergent results of $\mathrm{Cu}$ uptake among the cultivars after $\mathrm{N}-\mathrm{K}$ fertilization was attributed to the different productive capacities of the passion fruit plants, which can change the source-sink dynamics of nutrients in the plant organs according to higher or lower fruit production.

The $\mathrm{Fe}$ concentration and content in the standard leaves and those located in the adjacent position were not affected by the N-K application rates, except for Fe concentration in the leaf located in the position adjacent to the fruit of the cultivar Sol do Cerrado in which a quadratic increase was obtained after fertilization with the N-K application rates (Figure 3).

The increase in the leaf $\mathrm{Fe}$ concentration of the Sol do Cerrado cultivar can be explained by the increase in Fe demand in the plant as a constituent of the nitrate and nitrite reductase enzymes responsible for nitrogen assimilation and metabolism (VIANA; KIEHL, 2010). The intermediate $\mathrm{K}$ application rates (250-350 $\left.\mathrm{kg} \mathrm{ha}^{-1}\right)$ may also have favored Fe uptake by the Sol do Cerrado cultivar through increasing the synthesis of low molecular weight organic compounds, their exudation by the roots, and the formation of $\mathrm{Fe}$ organic mineral chelates in the soil solution (CARVALHAIS et al., 2011; WANG et al., 2013). Scientific studies have reported an increase in the concentrations of this nutrient as a result of nitrogen and potassium fertilization, as observed by Natale et al. (2006) and Resende et al. (2010).

Nevertheless, the lack of an effect of N-K fertilization on $\mathrm{Fe}$ uptake for most of the passion fruit cultivars studied and the presence of leaf concentrations considered adequate for development of the passion fruit plants indicate the lower effect of N-K fertilization on Fe uptake under conditions of adequate soil $\mathrm{Fe}$ availability to plants.

The increase in the $\mathrm{N}$ and $\mathrm{K}$ application rates did not affect the Mn concentrations and contents in the adjacent and standard leaves for the Gigante Amarelo and IAC 275 cultivars (Figure 3). In the Ouro Vermelho cultivar, there was an increase in the $\mathrm{Mn}$ concentration of the standard leaf as the $\mathrm{N}$ and $\mathrm{K}$ application rates increased (Figure 3 ). In the Sol do Cerrado cultivar, the increase in the $\mathrm{N}$ and $\mathrm{K}$ application rates (up to 165-413 and 153-394 $\mathrm{kg} \mathrm{ha}^{-1}$ ) increased the $\mathrm{Mn}$ concentrations in the standard leaf and $\mathrm{Mn}$ accumulated content in the adjacent leaves up to the application rates of 113-281 and 167-416 $\mathrm{kg} \mathrm{ha}^{-1}$ of $\mathrm{N}$ and $\mathrm{K}$ (Figure 3). However, application rates above these values reduced the concentrations and contents in these leaves, probably through having provided for $\mathrm{P}$ absorption by the synergistic effect of $\mathrm{N}$ application, reducing the mobility and translocation to the leaves by the formation of manganese phosphate.

One of the factors that also affected the concentrations of cationic micronutrients in the plants was the increase in potassium fertilization in the form of $\mathrm{KCl}$ by the negative effect of the $\mathrm{Cl}$ on uptake of these micronutrients by the plants, especially $\mathrm{Mn}$, $\mathrm{Zn}$, and $\mathrm{Cu}$ (PRADO et al., 2004), mainly brought about by leaching in the soil after the formation of complexes between these cationic micronutrients and the chloride anion.

The B concentrations were greater in the standard and adjacent leaves of the IAC 275 cultivar, with 58 and $64 \mathrm{mg} \mathrm{kg}^{-1}$, and lower in the standard and adjacent leaves of the Ouro Vermelho cultivar, with 55 and $59 \mathrm{mg} \mathrm{kg}^{-1}$, respectively (Figure 4). However, the B concentrations in the adjacent and standard leaves of the passion fruit plants were not affected by the $\mathrm{N}$ and $\mathrm{K}$ fertilization (Figure 4). Accumulated B content in the adjacent leaf of the Ouro Vermelho cultivar increased up to the recommended application rate of $\mathrm{N}$ and $\mathrm{K}$ equivalent to $150-375$ and $131-326 \mathrm{~kg} \mathrm{ha}^{-1}$, respectively (Figure 4). Above these application rates, there was a decrease in the leaf $\mathrm{B}$ concentrations, probably due to the inhibition strengthened by the increase in the availability of the $\mathrm{NO}_{3}{ }^{-}$and $\mathrm{Cl}^{-}$ions over the uptake of $\mathrm{H}_{2} \mathrm{BO}_{3}^{-}$(MALAVOLTA et al., 1989) after fertilization with high application rates of urea and $\mathrm{KCl}$. Prado et al. (2004) also observed that an increase in $\mathrm{KCl}$ application rates led to a reduction in $\mathrm{B}$ concentrations in the shoots of passion fruit seedlings. 
TABLE 1 - Chemical and physical composition of soil samples collected at the depths of 0-20 and 20-40 cm in the experimental area of the UNIMONTES experimental farm. Janaúba, MG, Brazil. 2014.

\begin{tabular}{|c|c|c|c|c|c|c|c|c|c|c|c|c|}
\hline Depth & $\mathrm{pH}^{1}$ & $\mathrm{OM}^{2}$ & $\mathrm{P}^{3}$ & $\mathrm{~K}^{3}$ & $\mathrm{Na}^{3}$ & $\mathrm{Ca}^{4}$ & $\mathrm{Mg}^{4}$ & $\mathrm{Al}^{4}$ & $\mathrm{H}+\mathrm{Al}^{5}$ & SB & $\mathrm{t}$ & $\mathrm{T}$ \\
\hline $\mathrm{cm}$ & & dag kg-1 & \multicolumn{2}{|c|}{$--\mathrm{mg} \mathrm{dm}^{-3}--$} & \multicolumn{8}{|c|}{------------------------- cmol $\mathrm{dm}^{-3}$--------------------- } \\
\hline $0-20$ & 5.9 & 2.9 & 3.9 & 156.0 & 0.1 & 3.0 & 1.2 & 0.0 & 1.3 & 4.7 & 4.7 & 6.0 \\
\hline $20-40$ & 5.4 & 1.4 & 3.6 & 95.0 & 0.2 & 2.6 & 0.8 & 0.0 & 1.3 & 3.8 & 3.8 & 5.1 \\
\hline Depth & $\mathrm{V}$ & $\mathrm{M}$ & $\mathrm{B}^{6}$ & $\mathrm{Cu}^{3}$ & $\mathrm{Fe}^{3}$ & $\mathrm{Mn}^{3}$ & $\mathrm{Zn}^{3}$ & P-rem ${ }^{8}$ & $\mathrm{EC}$ & Sand & Silt & Clay \\
\hline $\mathrm{cm}$ & \multicolumn{2}{|c|}{---- \% ----- } & \multicolumn{5}{|c|}{------------- mg dm ${ }^{-3}$---------- } & $\mathrm{mg} \mathrm{L}^{-1}$ & $\mathrm{dS} \mathrm{m}^{-1}$ & \multicolumn{3}{|c|}{------ dag kg-1 ----- } \\
\hline $0-20$ & 78.0 & 0.0 & 0.3 & 1.4 & 25.6 & 8.6 & 0.7 & 36.1 & 0.7 & 64 & 9 & 27 \\
\hline $20-40$ & 74.0 & 0.0 & 0.3 & 1.1 & 26.8 & 5.9 & 0.6 & 35.5 & 0.6 & 55 & 9 & 36 \\
\hline
\end{tabular}

${ }^{1} \mathrm{pH}$ in water; ${ }^{2}$ Colorimetry; ${ }^{3}$ Extractant: Mehlich-1; ${ }^{4}$ Extractant: $1 \mathrm{~mol} \mathrm{~L}-1 \mathrm{KCl} ;{ }^{5} \mathrm{pH}$ SMP; ${ }^{6}$ Extractant: $\mathrm{BaCl}_{2} ;{ }^{8}$ Equilibrium solution of P. SB, Sum of bases; t, effective CEC; T, CEC at pH 7; V, Base saturation; m, Aluminum saturation; P-rem, Remaining phosphorus EC, Electrical conductivity.

TABLE 2- Summary of analysis of variance of the data referring to dry matter weight (DM), concentration and content of $\mathrm{Zn}(\mathrm{ZnC}$ and $\mathrm{ZnA}), \mathrm{Cu}(\mathrm{CuC}$ and $\mathrm{CuA}), \mathrm{Fe}(\mathrm{FeC}$ and $\mathrm{FeA}), \mathrm{Mn}(\mathrm{MnC}$ and $\mathrm{MnA})$, and $\mathrm{B}(\mathrm{BC}$ and $\mathrm{BA})$ in the standard and adjacent leaves of the passion fruit plants (Cultivar) fertilized with $\mathrm{N}$ and K application rates. Janaúba, MG, Brazil. 2014.

\begin{tabular}{|c|c|c|c|c|c|c|c|}
\hline \multirow[b]{2}{*}{ SV } & \multicolumn{7}{|c|}{ MS (standard leaf) } \\
\hline & $\mathrm{DF}$ & DM & $\mathrm{ZnC}$ & $\mathrm{CuC}$ & $\mathrm{FeC}$ & $\mathrm{MnC}$ & $\mathrm{BC}$ \\
\hline Block & 2 & $0.7849 *$ & $15.4401^{\mathrm{ns}}$ & $102.0937^{*}$ & 4451.2884* & $70.0416^{\mathrm{ns}}$ & $9.3347^{\mathrm{ns}}$ \\
\hline Cultivar (C) & 3 & $1.5795 *$ & $140.1478^{\mathrm{ns}}$ & $6.7812^{\mathrm{ns}}$ & $308.8011^{\mathrm{ns}}$ & $926.8170 *$ & $48.3557^{*}$ \\
\hline Rate of $\mathrm{N}$ and $\mathrm{K}$ (D) & 5 & $0.2328 *$ & $82.8475^{\mathrm{ns}}$ & $14.3062 *$ & $631.6975^{*}$ & $819.3585^{*}$ & $16.9447^{*}$ \\
\hline$C$ versus D & 15 & $0.3018 *$ & $192.2220 *$ & $6.8562 *$ & $411.5568^{*}$ & $295.2813 *$ & $16.4695^{*}$ \\
\hline Residue & 46 & 0.0587 & 60.7935 & 3.2676 & 123.1445 & 140.2610 & 3.7357 \\
\hline $\mathrm{CV}(\%)$ & & 6.50 & 37.46 & 28.64 & 11.22 & 17.31 & 3.43 \\
\hline SV & $\mathrm{DF}$ & & $\mathrm{ZnA}$ & $\mathrm{CuA}$ & $\mathrm{FeA}$ & $\mathrm{MnA}$ & $\mathrm{BA}$ \\
\hline Block & 2 & & $0.0008^{\mathrm{ns}}$ & $0.0516^{*}$ & $5.6523 *$ & $0.0454^{\mathrm{ns}}$ & $0.0695 *$ \\
\hline Cultivar (C) & 3 & & $0.0761^{\mathrm{ns}}$ & $0.0037^{\mathrm{ns}}$ & $0.3598 *$ & $0.6735^{*}$ & $0.0045^{\text {ns }}$ \\
\hline Rate of $\mathrm{N}$ and $\mathrm{K}$ (D) & 5 & & $0.0341^{\mathrm{ns}}$ & $0.0094 *$ & $0.6702 *$ & $0.6811^{*}$ & $0.0253^{*}$ \\
\hline$C$ versus D & 15 & & $0.1448 *$ & $0.0041 *$ & $0.4067^{*}$ & $0.2366^{*}$ & $0.0314 *$ \\
\hline Residue & 46 & & 0.0375 & 0.0020 & 0.1001 & 0.1156 & 0.0082 \\
\hline \multirow[t]{2}{*}{$\mathrm{CV}(\%)$} & & & 35.80 & 27.92 & 12.03 & 18.84 & 6.12 \\
\hline & \multicolumn{7}{|c|}{ MS (adjacent leaf) } \\
\hline$\overline{\mathrm{SV}}$ & $\mathrm{DF}$ & DM & $\mathrm{ZnC}$ & $\mathrm{CuC}$ & $\mathrm{FeC}$ & $\mathrm{MnC}$ & $\mathrm{BC}$ \\
\hline Block & 2 & $0.3742 *$ & $28.9301^{\mathrm{ns}}$ & $30.3750^{\mathrm{ns}}$ & $2100.0104 *$ & $169.3359^{\mathrm{ns}}$ & $241.2139^{*}$ \\
\hline Cultivar (C) & 3 & $0.1447 *$ & $30.4186^{\mathrm{ns}}$ & $35.7500 *$ & $1855.0316^{*}$ & $977.0169 *$ & $81.9530 *$ \\
\hline Rate of N and K (D) & 5 & $0.0730 *$ & $67.6743 *$ & $12.0750^{\mathrm{ns}}$ & $541.7930^{\mathrm{ns}}$ & $858.2968 *$ & $19.2061^{\mathrm{ns}}$ \\
\hline$C$ versus D & 15 & $0.0453 *$ & $40.5631 *$ & $39.6250 *$ & $678.1716^{*}$ & $667.3994 *$ & $38.0826^{*}$ \\
\hline Residue & 46 & 0.0131 & 17.5670 & 11.8750 & 304.7917 & 273.4585 & 8.6050 \\
\hline $\mathrm{CV}(\%)$ & & 4.34 & 22.50 & 55.14 & 12.44 & 24.88 & 4.75 \\
\hline SV & $\mathrm{DF}$ & & $\mathrm{ZnA}$ & $\mathrm{CuA}$ & $\mathrm{FeA}$ & $\mathrm{MnA}$ & $\mathrm{BA}$ \\
\hline Block & 2 & & $0.0031^{\text {ns }}$ & $0.0201^{\mathrm{ns}}$ & $0.3130^{\mathrm{ns}}$ & $0.0047^{\mathrm{ns}}$ & $0.0017^{\text {ns }}$ \\
\hline Cultivar (C) & 3 & & $0.0577^{\mathrm{ns}}$ & $0.0581 *$ & $4.1960 *$ & $2.6820 *$ & $0.2209 *$ \\
\hline Rate of N and K (D) & 5 & & $0.1284^{*}$ & $0.0146^{\mathrm{ns}}$ & $1.2663^{*}$ & $1.6452 *$ & $0.1562 *$ \\
\hline$C$ versus D & 15 & & $0.0636^{*}$ & $0.0424 *$ & $1.3192 *$ & $1.0077 *$ & $0.1556^{*}$ \\
\hline Residue & 46 & & 0.0249 & 0.0143 & 0.4807 & 0.4619 & 0.0306 \\
\hline CV $(\%)$ & & & 22.79 & 52.28 & 13.33 & 27.32 & 7.63 \\
\hline
\end{tabular}

ns - not significant, $*$ - significant at $5 \%$ probability by the $\mathrm{F}$ test 


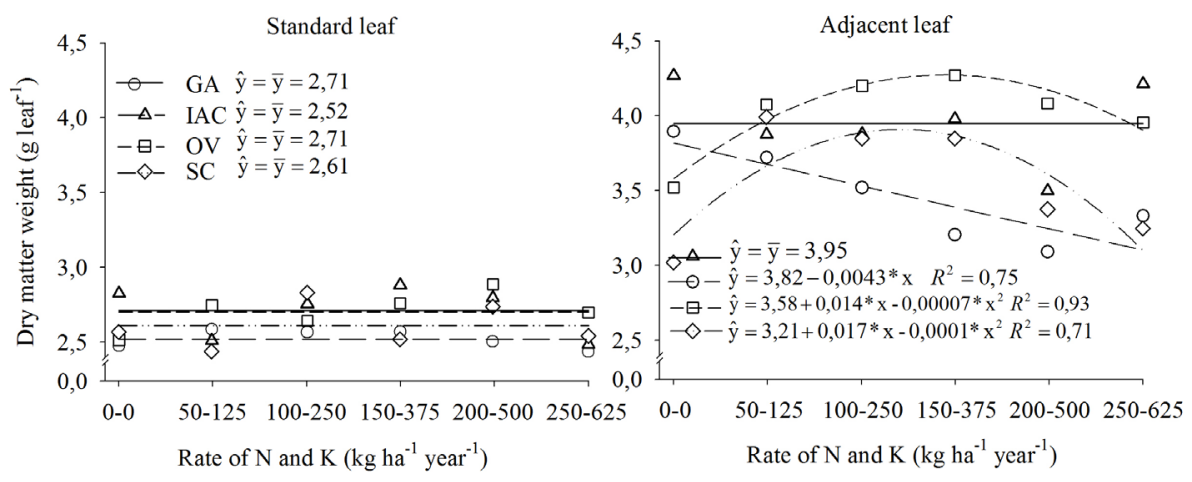

FIGURE 1-Mean of dry matter weight of the leaf collected from the position adjacent to the fruit (adjacent leaf) and 4th leaf of the fruit-bearing branch (standard leaf) of passion fruit cultivars under fertilization with application rates of $\mathrm{N}$ and $\mathrm{K}$, through the soil.

*: significant at 5\% probability. Janaúba, MG, Brazil. 2014.
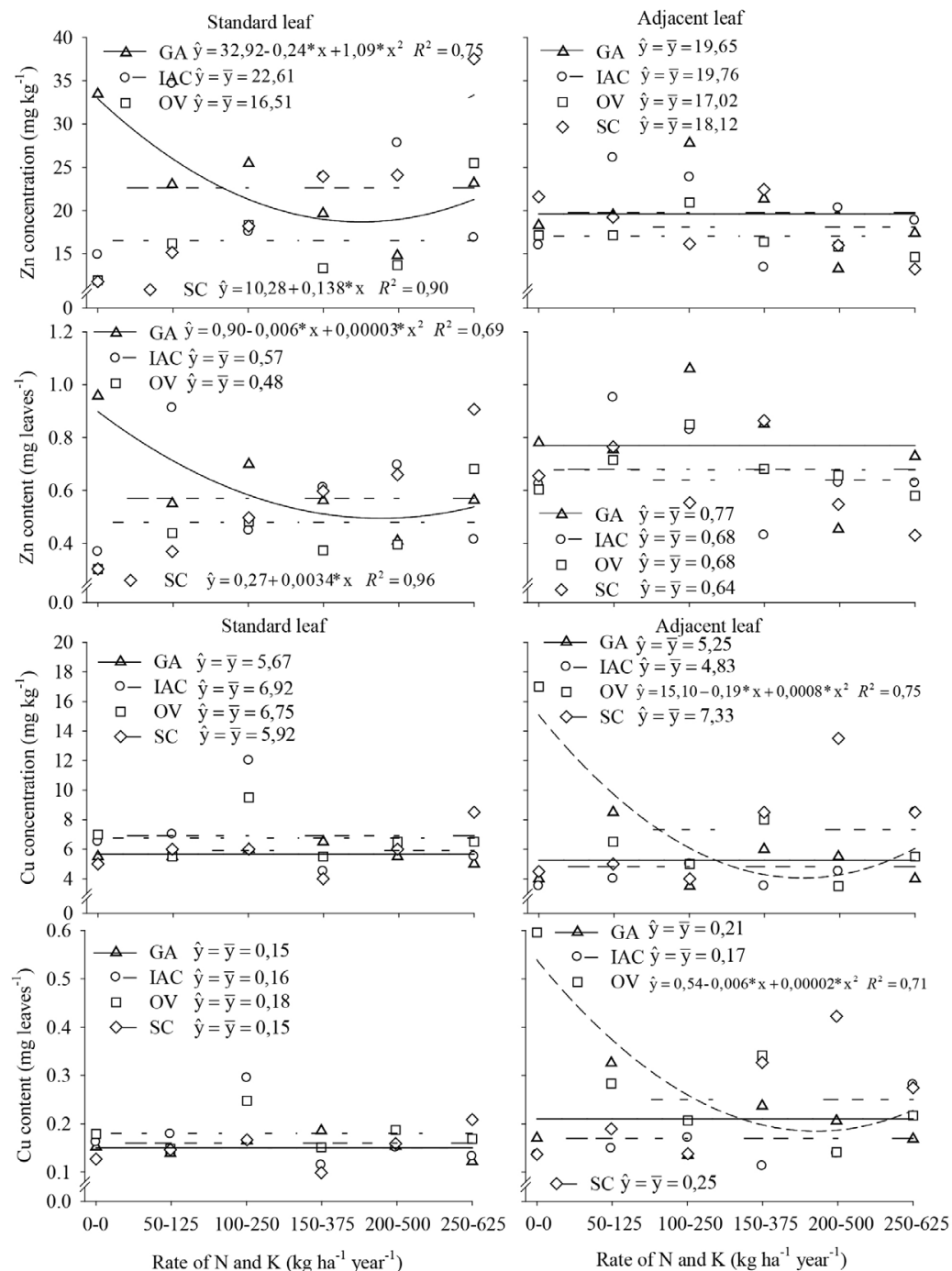

FIGURE 2-Concentration and content of $\mathrm{Zu}$ and $\mathrm{Cu}$ in leaf samples collected from the position adjacent the fruit (adjacent leaf) and at the end of the fruit-bearing branch (standard leaf) of passion fruit cultivars under fertilization with application rates of $\mathrm{N}$ and $\mathrm{K}$ through the soil.

*: significant at 5\% probability. Janaúba, MG, Brazil. 2014. 

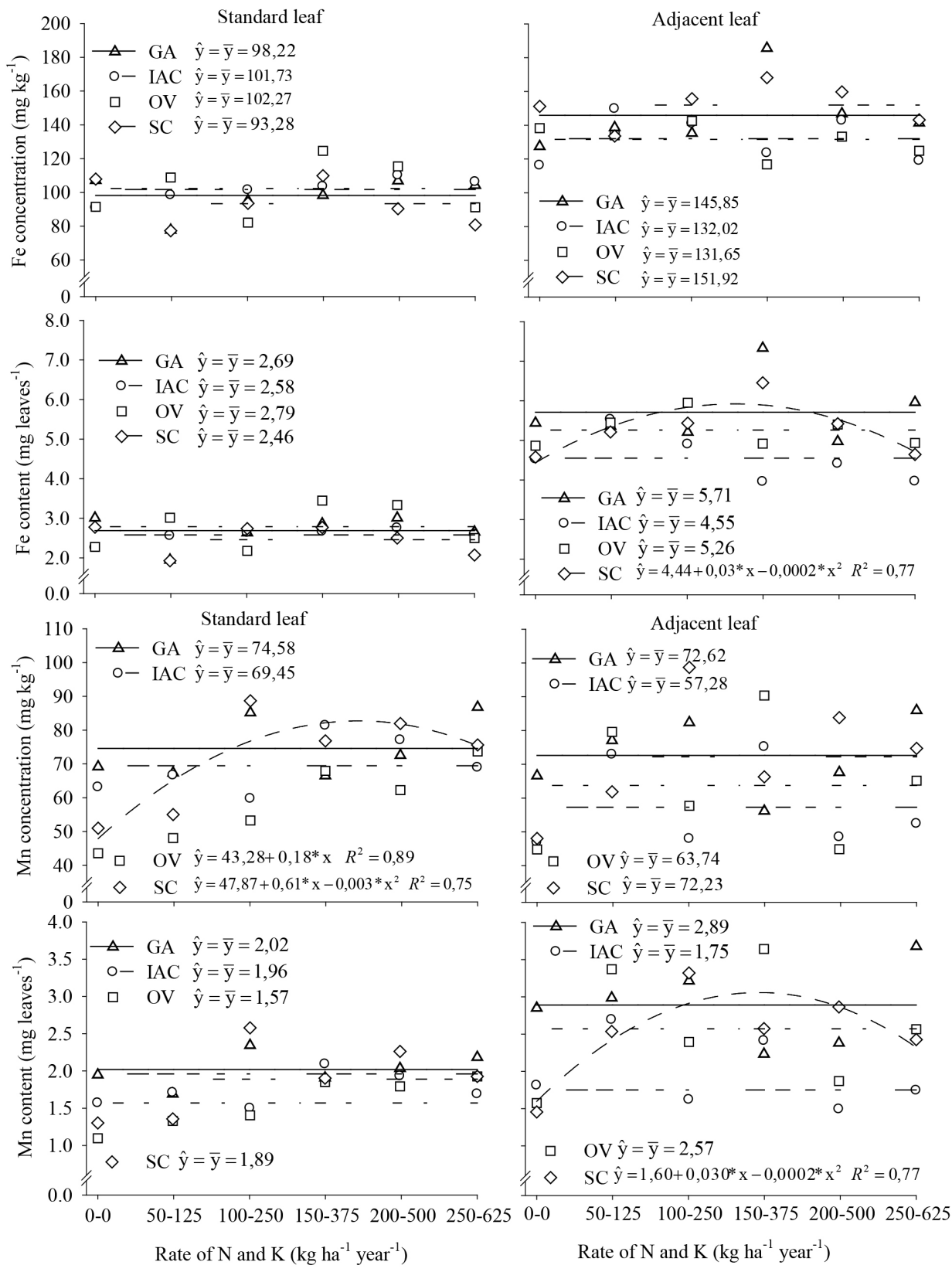

FIGURE 3- Concentration and content of $\mathrm{Fe}$ and $\mathrm{Mn}$ in leaf samples collected from the position adjacent to the fruit (adjacent leaf) and at the end of the fruit-bearing branch (standard leaf) of passion fruit cultivars under fertilization with application rates of $\mathrm{N}$ and $\mathrm{K}$ through the soil.

*: significant at 5\% probability. Janaúba, MG, Brazil. 2014. 

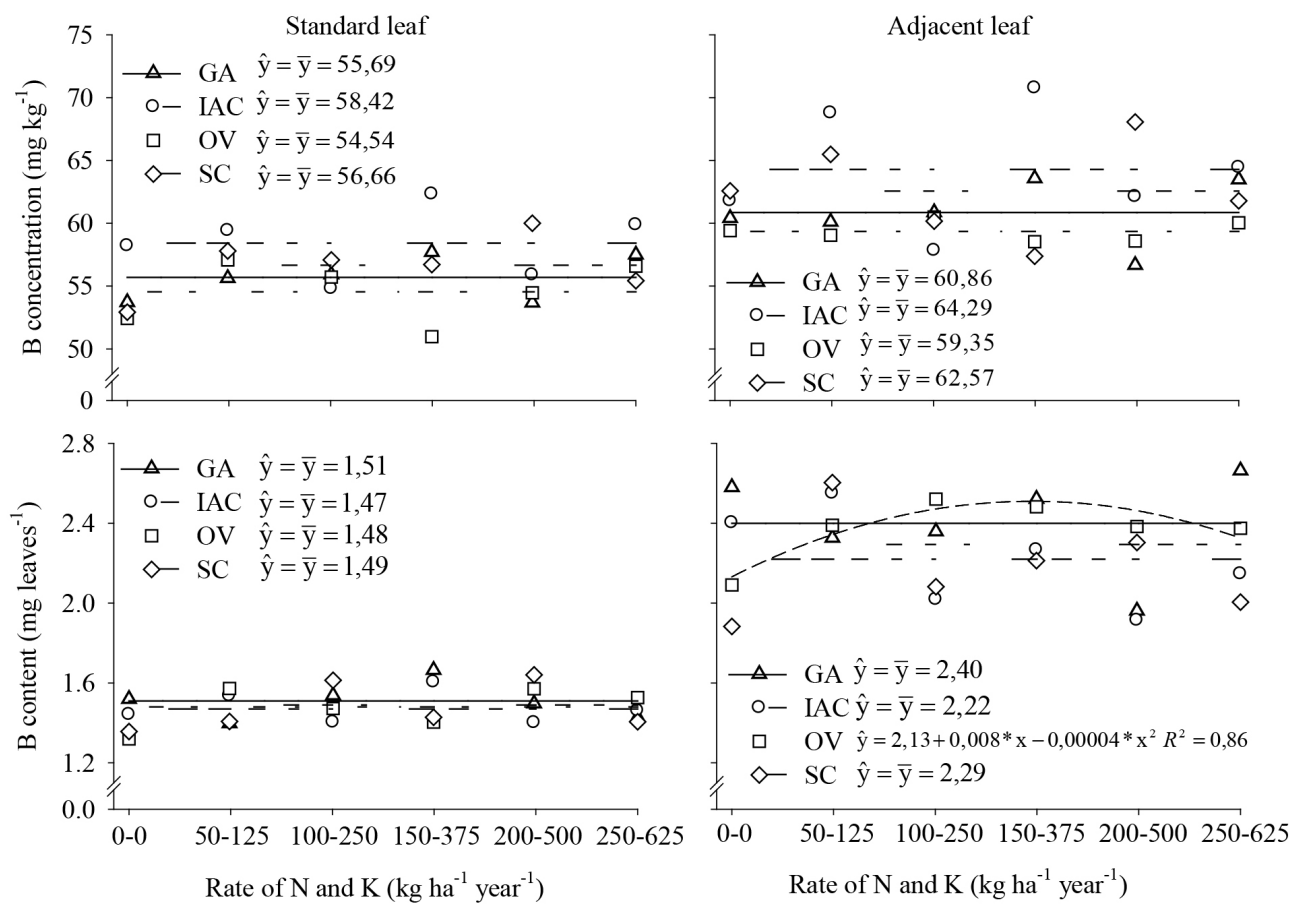

FIGURE 4- Concentration and content of $B$ in leaf samples collected from the position adjacent to the fruit (adjacent leaf) and at the end of the fruit-bearing branch (standard leaf) of passion fruit cultivars under fertilization with application rates of $\mathrm{N}$ and $\mathrm{K}$ through the soil.

*: significant at 5\% probability. Janaúba, MG, Brazil. 2014.

\section{CONCLUSIONS}

High $\mathrm{N}$ and $\mathrm{K}$ application rates inhibit uptake of $\mathrm{Zn}$ by the passion fruit Gigante Amarelo cultivar and of $\mathrm{Cu}$ in the Ouro Vermelho cultivar.

Increases in the $\mathrm{N}$ and $\mathrm{K}$ application rates do not change the concentrations and contents of $\mathrm{Mn}$ in the adjacent and standard leaves of the cultivars Gigante Amarelo and IAC 275, and they do not affect the concentration and content of $\mathrm{B}$ in the standard leaves of any of the passion fruit cultivars evaluated.

The IAC 275 cultivar exhibits lower accumulations of $\mathrm{Cu}, \mathrm{Fe}$, and $\mathrm{Mn}$ in the adjacent leaf in comparison to the other cultivars.

\section{ACKNOWLEDGMENTS}

The authors thank the Foundation for Research Support of Minas Gerais (FAPEMIG), National Council for Scientific and Technological Development (CNPq) and Pro-Rectory Research of Federal University de Minas Gerais (PRPq-UFMG) for financial and scholarship support. We also thank the CNPq for the Research Productivity Grant to the second and fourth author.

\section{REFERENCES}

ABREU, C.A.; LOPES, A.S.; SANTOS, G.C.G. Micronutrientes. In: NOVAIS, R.F.; ALVAREZ, V.H.; BARROS, N.F.; FONTES, R.L.F.; CANTARUTTI, R.B.; NEVES, J.C.L. Fertilidade do solo. Viçosa: Sociedade Brasileira de Ciência do Solo, 2007. p.645-736.

ALMEIDA, L.H.C.; OLIVEIRA, E.C.; FRATONI, M.M.J.; FREGONEZI, G.A.F.; TAKAHASHI, H.W. Effect of potassium doses fertirrigated in the nutritional contents of tomato fruit and leaves in their early development. African Journal of Agricultural Research, Ago Iwoye, v.10, n.47, p.4275-4282, 2015.

BORGES, A.L.; CALDAS, R.C.; LIMA, A.A.; AMEMEIDA, I.E. Efeito de doses de NPK sobre os teores de nutrientes nas folhas e no solo, e na produtividade do maracujazeiro amarelo. Revista Brasileira de Fruticultura, Jaboticabal, v.24, n.1, p.208-213, 2002. 
BORGES, A.L.; RODRIGUES, M.G.V.; LIMA, A.A.; ALMEIDA, I.E.; CALDAS, R.C. Produtividade e qualidade de maracujá-azedo irrigado, adubado com nitrogênio e potássio. Revista Brasileira de Fruticultura, Jaboticabal, v.25, n.2, p.259-262, 2003.

CAIRES, E.F.; MILLA, R. Adubação nitrogenada em cobertura para o cultivo de milho com alto potencial produtivo em sistema de plantio direto de longa duração. Bragantia, Campinas, v.75, n.1, p.8795, 2016

CAKMARK, I. Plant nutrition research: Priorities to meet humam needs for food in sustainable ways. Plant and Soil, Dordrecht, v.247, n.1, p.3-24, 2002.

CARVALHAIS, L.C.; DENNIS, P.G.; FEDOSEYENKO, D.; HAJIREZAEI, M.R.; BORRISS, R.; VON WIRÉN, N. Root exudation of sugars, amino acids, and organic acids by maize as affected by nitrogen, phosphorus, potassium, and iron deficiency. Journal of Plant Nutrition and Soil Science, Weinheim, v.174, n.1, p.3-11, 2011.

EMBRAPA. Manual de métodos de análise de solo. 2. ed. Rio de Janeiro: Centro Nacional de Pesquisa de Solos, 1997. 212 p.

EMBRAPA. Sistema brasileiro de classificação de solos. 3.ed. Brasília, DF, 2013.353 p.

FERREIRA, D.F. Sisvar: a computer statistical analysis system. Ciência \& Agrotecnologia, Lavras, v.35, n.6, p.1039-1042, 2011.

FREITAS, M.S.M.; MONNERAT, P.H.; VIEIRA, I.J.C.; CARVALHO, A.J.C. Flavonóides e composição mineral de folhas de maracujazeiro amarelo em função da posição da folha no ramo. Ciência Rural, Santa Maria, v.37, n.6, p.1634-1639, 2007.

IBGE - Instituto Brasileiro de Geografia e Estatística. Produção agrícola municipal: culturas temporárias e permanentes. Rio de Janeiro, 2013. v.40, p.1-102.

LIZARAZO, M.A.; HERNÁNDEZ, C.A.; FISCHER, G.; GÓMEZ, M.I. Response of the banana passion fruit (Passiflora tripartite var.mollissima) to different levels of nitrogen, potassium and magnesium. Agronomía Colombiana, Bogotá, v.31, n.2, p.184194, 2013.
MALAVOLTA, E; VITTI, G.C.; OLIVEIRA, S.A. Avaliação do estado nutricional das plantas: princípios e aplicações. 2.ed. Piracicaba: POTAFOS, 1997. 319 p.

MALAVOLTA, E.; VITTI, G.C.; OLIVEIRA, S.A. Avaliação do estado nutricional das plantas: princípios e aplicações. Piracicaba: POTAFOS, 1989. 201 p.

MARCHAL, J.; BOURDEAUT, J. Leaf sampling of passion fruit (Passiflora edulis Sims.var.flavicarpa). Fruits, Paris, v.27, n.2, p.307-311, 1972.

MARSCHNER, H. Mineral nutrition of higher plants. $2^{\text {nd }}$ ed. San Diego: Academic, 1995. 889 p.

MENEZES, E.F.; CAVALCANTE, L.F.; MESQUITA, F.O.; CAMPOS, V.B.; DANTAS, T.A.G. Composição mineral do maracujazeiro amarelo em resposta ao biofertilizante bovino e cloreto de potássio no solo. Revista Brasileira de Ciências Agrárias, Recife, v.7, n.2, p.260-268, 2012.

MUNER, L.H.; RUIZ, A.H.; VENEGAS, V.H.V.; NEVES, J.C.L.; FERNANDO J.FREIRE, F.J.; FREIRE, M.B.G.S. Disponibilidade de zinco para milho em resposta à localização de fósforo no solo. Revista Brasileira Engenharia Agrícola e Ambiental, Campina Grande, v.15, n.1, p.29-38, 2011.

NATALE, W.; PRADO, R.M.; ALMEIDA, E.V.; BARBOSA, J.C. Adubação nitrogenada e potássica no estado nutricional de mudas de maracujazeiroamarelo. Acta Scientiarun Agronomy, Maringá, v.28, n.2, p.187-192, 2006.

NEVES, O.S.C.; CARVALHO, J.G.; FERREIRA, E.V.D.O.; ASSIS, R.P. Nutrição mineral, crescimento e níveis críticos foliares de cálcio e magnésio em mudas de umbuzeiro, em função da calagem. Ceres, Viçosa, v.55, n.6, p.575-583, 2008.

OLIVEIRA, A.M.G.; NATALE, W.; ROSA, R.C.C.; JUNGHANS, D.T. Adubação N-K no abacaxizeiro 'BRS Imperial' - I - Efeito no desenvolvimento e na floração da planta. Revista Brasileira de Fruticultura, Jaboticabal, v.37, n.3, p.755-763, 2015 . 
PETTIGREW, W.T. Potassium influences on yield and quality production for maize, wheat, soybean and cotton. Physiologia Plantarum, Copenhagen, v.133, n.4, p.670-681, 2008.

PRADO, R.M.; BRAGHIROLLI, L.F.; NATALE, W.; CLEBER, M.; CORRÊA, M.; ALMEIDA, E.V. Aplicação de potássio no estado nutricional e na produção de matéria seca de mudas de maracujazeiroamarelo. Revista Brasileira de Fruticultura, Jaboticabal, v.26, n.2, p.295-299, 2004.

RESENDE, G.M.; ALVARENGA, M.A.R.; YURI, J.E.; SOUZA, R.J. Doses de nitrogênio e molibdênio no rendimento e teor de micronutrientes em alface americana. Horticultura Brasileira, Brasília, DF, v. 28 n.3, p.266-270, 2010.

RODRIGUES, M.G.V.; PACHECO, D.D.; NATALE, W.; SILVA, J.T.A. Amostragem foliar da bananeira 'Prata-Anã'. Revista Brasileira de Fruticultura, Jaboticabal, v.32, p.321-325, 2010.

SANTOS, A.L. Estabelecimento de normas de amostragem foliar para avaliação do estado nutricional e adubação mineral do coqueiro anão verde na região do norte fluminense. 2002.82 f. Tese (Doutorado em Produção Vegetal) Universidade Estadual do Norte Fluminense Darcy Ribeiro, Campos dos Goitacazes, 2002.

SILVA JÚNIOR, G.B.; CAVALCANTE, Í.H.L.; ALBANO, F.G.; OSAJIMA, J.A. Estado nutricional e clorofila foliar do maracujazeiro-amarelo em função de biofertilizantes, calagem e adubação com N e K. Revista de Ciências Agrárias, Recife, v.36, n.2, p.163-173, 2013.
SILVA, A.A.G.; KLAR, A.E. Demanda hídrica do maracujazeiro amarelo (Passiflora edulis Sims f.flavicarpa Deg.). Irriga, Botucatu, v.7, n.3, p.185190, 2002.

SILVA, F.C.D.S. Manual de análises químicas de solos, plantas e fertilizantes. 2.ed. Brasília, DF: Embrapa Informação Tecnológica, 2009. 627 p.

SOUSA, V.F.; BORGES, A.L. Irrigação e fertirrigação na cultura do maracujá.In: SOUSA, V.F.; MAROUELLI, W.A.; COELHO, E.F.; PINTO, J.M.; COELHO FILHO, M.A.(Ed.). Irrigação e fertirrigação em fruteiras e hortaliças .Brasília, DF: Embrapa Informação Tecnológica, 2011. cap. 17 , p.501-522.

SOUZA, L.B.; HEITOR, L.C.; SANTOS, P.C.; FREITAS, J.A.A.; FREITAS, M.S.M.; FREITAS, S.J.; CARVALHO, A.J.C. Crescimento, composição mineral e fenóis totais de espécies de Passiflora em função de fontes nitrogenadas. Bragantia, Campinas, v.72, n.3, p.247-254, 2013.

VIANA, E.M.; KIEHL, J.C. Doses de nitrogênio e potássio no crescimento do trigo. Bragantia, Campinas, v.69, n.4, p.975-982, 2010.

WANG, M.; ZHENG, Q.; SHEN, Q.; GUO, S. The critical role of potassium in plant stress response. International Journal of Molecular Sciences, Basel, v.14, n.4, p.7370-7390, 2013. 